\title{
On the Confusion of the Terms dualis and communis in Cledonius
}

\author{
Vlada A. Chernysheva
}

St. Petersburg State University,

7-9, Universitetskaya nab., St. Petersburg, 199034, Russian Federation; chernyshe.va@mail.ru

For citation: Chernysheva V. On the Confusion of the Terms dualis and communis in Cledonius. Philologia Classica 2021, 16 (1), 100-105. https://doi.org/10.21638/spbu20.2021.109

This article attempts to provide an interpretation of a passage on the noun number written by the 5th-century grammarian Cledonius who composed a lemmatised commentary on Donatus' Ars minor and Ars maior. The passage discussed here is a part of the explanation regarding the noun categories in Ars minor: Numerus, qui unum et plures demonstrat: et communis est numerus, qui et dualis dicitur apud Graecos, ut species facies res. (GL V 10. 19-20). Cledonius' text confuses two terms dualis and communis, which normally signify different linguistic phenomena. Tim Denecker, whose article covers the history of the term dualis in Latin grammatical treatises, argues that dualis in this passage is indicating a pair and is equated to communis. The aim of the present work is to explain why these two terms have been confused. When comparing Greek and Latin, the Roman grammarians Charisius, Diomedes, Priscian, and Macrobius highlighted the absence of the dual number from Latin, whereas Donatus added it to the singular and plural exemplifying it with two nomina - duo and ambo. Having analysed all of Cledonius' passages on dualis and communis and compared them with the original text of Donatus, one may notice that Cledonius did not make comments on Donatus' observations concerning the dual number of $d u o$ and ambo. In the author's view, the grammarian may have opined that the Latin language had no dual number at all, so that in his commentary Latin communis is juxtaposed to Greek dualis and both are opposed to singular and plural.

Keywords: category of number, dual number, Latin linguistics, Roman grammarians, history of linguistics, Cledonius.

The history of the term dualis is thoroughly covered in Tim Denecker's article "Ambo legere? The 'dual number' in Latin grammaticography up to the medieval artes." Nevertheless, there is a case where dualis is treated in a peculiar manner, and, thus, it needs to be revisited. The passage is from the lemmatised commentary written by Cledonius, the

(C) St. Petersburg State University, 2021 
commentator of Donatus' grammar, who lived in Constantinople in the mid-fifth century A. D. (Zetzel 2018, 291):

(1) Numerus, qui unum et plures demonstrat: et communis est numerus, qui et dualis dicitur apud Graecos, ut species facies res. (GL V 10. 19-20)

"Number, which shows one and many: there is also 'commune number', which is called 'dualis' among Greeks, for example, species 'sight(s)', facies 'face(s)', res 'thing(s)"'

Denecker interprets this passage as follows: "As can be seen from this series of examples, Cledonius has entirely equated the dualis numerus to the communis numerus for nouns - which is an exceptional point of view - although his remark that the term 'dual' is typically Greek does reflect an awareness of its 'proper' or 'original' value, which consists in indicating a pair" (Denecker 2019, 119). This comment raises the question why such an equation between the two terms came into existence.

The quotation in (1) is Cledonius' explanation of the term numerus 'number' mentioned in the following passage of Donatus' Ars minor, which describes categories of nomen, i. e., nouns and adjectives:

(2) Nomini quot accidunt? Sex. Quae? Qualitas, conparatio, genus, numerus, figura, casus. (Donat. 585. 8-9 Holtz)

"How many categories are assigned to noun? Six. Which? Quality, comparison, gender, number, figure, case."

Since Cledonius had touched upon the issue of the noun number in (1), it seems surprising that another passage from Ars minor (3), which also deals with noun number, was neglected by the commentator:

(3) Numeri nominum quot sunt? Duo. Qui? Singularis, ut hic magister; pluralis, ut hi magistri. (Donat. 586. 9-10 Holtz)

"How many noun numbers are there? Two. Which? Singular, as hic magister 'this teacher', plural, as hi magistri 'these teachers"'

It is worth noticing that Ars minor does not provide any information neither on $n u$ merus dualis nor on numerus communis, which suggests that Cledonius gained information from some other sources. The article on dualis in Thesaurus Linguae Latinae questions the correctness of his passage: male numerum dualem et communem q.d. confundit Cledon. Gramm. V. 10, 20 (TLL 5, 1: 2072).

To begin with, it is necessary to locate the dual number in the Latin language system and to outline the usual meaning of the term dualis among Roman grammarians. As is commonly known, the Latin language system has not preserved the Indo-European category of dualis except for the numerals $d u o$ and $v i g i n t i{ }^{1}$ and the pronoun $a m b o .^{2}$ As far as

${ }^{1}$ On the etymology of viginti, see de Vaan 2008, 678; Ernout 1953, 4: "Létymologie permet de reconnaître d'anciennes formes de duel; mais pour le sujet parlant, vīgintī était un indéclinable dont on ne distinguait plus les éléments de formation".

2 Panhuis 2006, 16; Ernout 1953, 4-5: "duo et ambō se comportaient comme des pluriels, dans leur flexion comme dans leur emploi". 
grammarians are concerned, Charisius, Diomedes and Priscian claimed that there was no dual number in Latin: ${ }^{3}$

(4) Dualis enim apud Romanos non est. (Charis. 15. 22-23=195. 2-3 Barwick)

"Since there is no dual used by Romans."

(5) Dualis enim apud Graecos dumtaxat valet, a nobis excluditur, eodem modo quo et in nominibus. Nequaquam enim reperiri potest Latino sermone ulla dictio quae dualem exprimat numerum. (GL I 334. 26-28 (Diom.))

"Dual is of value only to the Greeks, while it is excluded by us in a similar way as done to nouns. Therefore, no word could be found in the Latin language which would express dual number."

(6) Numerus est dictionis forma, quae discretionem quantitatis facere potest. Est autem vel singularis vel pluralis, nam dualis apud Latinos non invenitur. (Prisc. I 172. 2-4 Hertz)

"Number is a form of speech which can express quantity. It is either singular or plural, since dual does not occur among Latin-speakers."

Nevertheless, an implicit, as in examples (4)-(6), or explicit comparison with the Greek language stimulated Roman grammarians to write on the dual number, as Macrobius does:

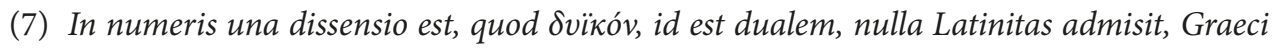

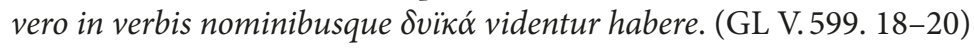

“There is one disagreement between numerals that Latin does not admit Svïkóv, i. e. dual,

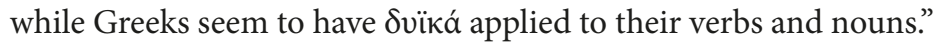

The adjective dualis, as we see, is contrasted by Roman grammarians to singular and plural as in examples (4)-(7). It deals with the category of number and indicates that there are two objects which are referred to in a sentence. The only exception ${ }^{4}$ from the wellestablished word meaning can be observed in (1), where the term dualis is treated as the original Greek term for Latin communis and there is no grammatical duality expected. At first glance, the only explanation to be suggested is as follows: the term dualis could imply that the word form which is determined as dualis can be interpreted ambivalently and, therefore, should be understood, for example, as a specific synonym for the Latin adjective ambiguus. There is a point of intersection for dualis and communis here: if an 'ambiguous' noun form could be considered either singular or plural, grammarians described it as a 'common' number form, see TLL 3. 1978-1979.

${ }^{3}$ Pseudo-Asper expresses this idea in a trickier way. I agree with Tim Denecker $(2019,106)$, who suggests that the passage below implies the absence of the dual number from Latin since its pronouns are realised in four variants, while Greek offers nine, GL V 550. 39-551. 1: Numerus apud Graecos propter dualem numerum motus habet nouem, in sermone nostro quatuor: aut enim unum unius significamus, ut meus tuus, aut multos multorum, ut nostri uestri, aut unum multorum, ut noster uester, aut multos unius, ut mei tui. ("Greek number has nine operations because of dual, while there are four of them in our language: we signify either one of the one, as meus 'my (sg.)', tuus 'your (sg.)', many of many, as nostri 'our (pl.)', vestri 'your (pl.)', one of the many, as noster 'our (sg.)', vester 'your (sg.)', or many of the one, as mei 'my (pl.)', tui 'your (pl.)"')

4 All the examples of dualis were found via wordlist search in Corpus corporum (Corpus 13 Grammatici Latini): http://www.mlat.uzh.ch/MLS/ (26.02.2021). 
Having clarified how other authors treated the terms dualis and communis, I now turn back to Cledonius in an attempt to find some other examples elsewhere in his text. There are only two passages left (see 8 and 9) where dualis and communis express the number. Both are fragments of the commentary on Donatus' Ars maior and contain lemmata (below in bold). Example (8) includes a note on the common number of nomina, whereas example (9) mentions the dual number of verbs.

(8) sunt etiam numero communia: in tertia quarta et quinta declinatione communis numerus invenitur. Communia, <ut res>nubes dies: haec res hae res. (GL V 42. 15-17 (Cledon.))

"There are also [nouns] common in number: the common number is found in the third, fourth and fifth declension. Common, for example, are res 'thing(s)', nubes 'cloud(s)', dies 'day(s)': haec res 'this thing, hae res 'these things.'

(9) Numeri verbis accidunt duo, singularis et pluralis, singularis, ut lego, pluralis, ut legimus; item secundum quosdam dualis, ut legere: propter metrum legere prudentius dicimus, quod significat legerunt, ut Vergilius 'legere rudentis. ${ }^{5}$ Ideo dualis dicitur numerus, quia duas personas a plurali numero tertia persona sibi defendit. (GL V 60. 2-7 (Cledon.))

"There are two numbers, which are assigned to verbs, singular and plural: singular, lego 'I read', plural, legimus 'we read'; according to some [grammarians], there is also a dual one, as legere: we say legere, which means legerunt, because of the metre, for example, legere rudentis in Virgil. Therefore, the number is called dual for the reason that it reclaims two persons from the third person plural."

Let us take a look at the common number first. When trying to explain nomina numero communia in (8), Cledonius splits the original clause in (10) into two parts:

(10) Sunt etiam nomina numero communia, ut res, nubes dies. (Donat. 623. 1 Holtz)

“There are also nouns common in number, for example, res 'thing(s)', nubes 'cloud(s)', dies 'day(s)"'

In example (10), Cledonius does not move beyond Donatus' theory and does not draw any parallels with dualis, as he did in example (1). It is to be stressed that since there is no duality mentioned in (8), Denecker certainly does not include this contrasting example in his passage on Cledonius, so that only (1) and (9) are analysed in his paper, see Denecker 2019, 119.

Surprisingly, Cledonius omits the following statement of Donatus on the dual of nomina:

${ }^{5}$ Regarding the quotation, Heinrich Keil, the editor of the text, suggests that Cledonius lacks a real quotation from Virgil since legere rudentis is borrowed from Lucan's De Bello Civili (3. 44). On the contrary, there are two instances from Virgil's Georgica selected by Keil which contain the verb form legere. See the apparatus in GL V 60. One more example of quoting legere rudentes (sic!) is found in Pompeius' commentary on Donatus, however, without mentioning the author, GL V 234. 30-32: Puta 'legere rudentes': legere rudentes stat; legerunt rudentes, non stat uersus. Ergo quoniam sunt aliqua, ubi exigatur breuis syllaba, aliqua, ubi longa, ideo duplicem regulam fecerunt. ("For example, legere rudentes: legere rudentes fits, legerunt rudentes does not fit the verse. Therefore, since somewhere a short syllable is called for, somewhere a long one, a 'double' rule is made.") 
(11) Numeri sunt duo, singularis et pluralis: singularis, ut hic sapiens, pluralis, ut hi sapientes. Est et dualis numerus, qui singulariter enuntiari non potest, ut hi ambo, hi duo. (Donat. 622. 10-12 Holtz)

"There are two numbers, singular and plural: singular, as hic sapiens 'this wiseman', plural, as hi sapientes 'these wisemen'. There is also a dual number, which cannot be expressed in singular, as hi ambo 'these both', hi duo 'these two."'

In (11), Donatus places the dual number after the singular and plural by contrast to the authors of passages (4)-(7), and exemplifies it with duo and ambo. After Donatus, the dual of duo and ambo is attested in Servii Commentarius in Artem minorem (GL IV 408. 17-19), in the commentary of Sergius (65 Stock), with added uterque (however, put in braces by the editor) in Consentius (GL V 347. 32-348. 1) and Audax (GL VII 343. 1920), uter and neuter in Explanationes in Artes Donati (GL IV 540. 6-8). Primarily, dualis numerus is based on the inner meaning, which is embodied in the word dualitas in frg. Bobiense de verbo (24 Passalacqua) and in the term significatio dualis in Regulae Ps. $-A u$ gustini (GL V 508. 18-20). Besides semantics, a peculiar inflection type of dual, different from singular and plural, is highlighted by Servius in his commentary on Donatus' Ars minor (GL IV 408.17-19).

The other type of dualis which was mentioned by Roman grammarians is the dualis of the verbs. It can be observed in example (9). The text in bold is a quotation from Donatus' Ars maior (637. 4-5 Holtz). Donatus, however, does not appear to be the first grammarian who supported this linguistic hypothesis. There is a passage with other verb examples from Sacerdos' Artes grammaticae (the late 3rd century A. D., see Zetzel 2018, 318):

(12) Numeri in verbis tot sunt quot et in nominibus, singularis, ut amo, pluralis, ut amamus. Numerum uero dualem etiam quidam putant esse, cum dicimus dixere scribsere, quod est pro scribserunt dixerunt. (GL VI 432.7-9)

"Verbs have as many numbers as nouns do, singular amo 'I love', plural amamus 'we love'. Some, however, believe that the dual number also exists, when we say dixere, scribsere, which are used instead of scribserunt 'they wrote', dixerunt 'they said"'

Here, it can be observed that from the standpoint of unknown early grammarians, the dual number is applicable to the verb or, to be exact, only to 3 pl. active perfect forms ending in -re. Two variants of the third person non-singular form were supposed to be functionally different. While Donatus (11) and Sacerdos (12) do not object to the 'dualis hypothesis' in an explicit way, the grammarian Consentius (late 4 th or early 5 th century A. D., see Zetzel 2018, 291) expresses strong dissent, as follows:

(13) <...> legere autem dualem esse dicunt, ut hoc de duobus recte dici videatur, legerunt autem de pluribus. Sed hanc adsertionem usus inprobavit. Itaque ex consuetudine pluralem utrumque dicimus. (GL V 379. 6-9)

" $<\ldots>$ on the other hand, legere is said to be dual, so that, as applied to two, it seems to sound correctly, while legerunt concerns many. However, practice has not proved this assertion. Therefore, we call both plural from habit."

As can be seen from examples (8) and (9), Cledonius understands clearly what the common number of the nomina is and what the dual number of the verbs was considered to be, although he does not support this hypothesis. Aside from that, he explains the 
meaning of the term dualis in (9), so that the 'ambiguous' interpretation of dualis suggested earlier is problematic. On the other hand, the dual number of nomina is absent in his commentaries both on Ars minor and Ars maior. This fact may imply that Cledonius excluded the dual number of nomina and verbs from the Latin language. Thus, it could be presumed that Cledonius distinguished three numbers in Latin, as Ps.-Asper did:

(14) Numeri accidunt duo, singularis, ut hic Cato, pluralis, ut hi Catones, communis, ut dies nubes. (GL V 550. 3-4)

"There are two numbers applied: singular, as hic Cato 'this Cato', plural, as hi Catones 'these Catones', common, as dies 'day(s)', nubes 'cloud(s).'

As far as the confusion of the terms is concerned, Cledonius might have been aware of the original meaning of dualis, "which consists in indicating a pair" (see Denecker 2019, 119): the grammarian might have interpreted 'a pair' as 'a pair of meanings applied to one

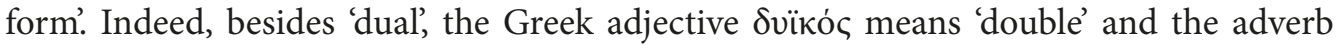

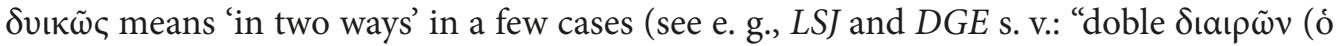

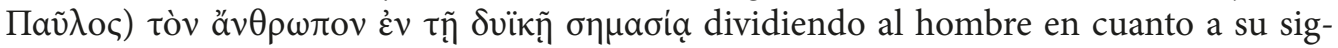

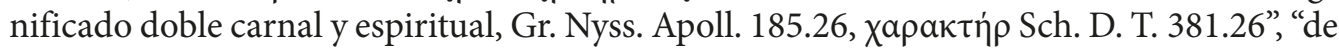

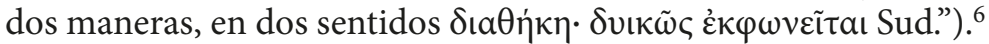

However, the 'ambiguous' inner meaning of dualis, if accepted, seems to be just one of the factors. I suggest that the equation of the two terms actually happened for another reason. Cledonius juxtaposes two number oppositions implicitly: singularis - pluralis communis for Latin and singularis - pluralis - dualis for Greek, where communis and dualis are 'extra numbers' by contrast to singularis and pluralis. Since dual is a feature of Greek, as shown in (4)-(7), and Cledonius probably saw fit to exhibit his learnedness, he adds qui et dualis dicitur apud Graecos, but applies it to communis numerus.

\section{References}

Barwick K. (ed.) Flauii Sosipatri Charisii Artis grammaticae libri V, addenda et corrigenda collegit F. Kühnert. Leipzig, Teubner, ${ }^{2} 1964$.

Denecker T. Ambo legēre? The 'dual number' in Latin grammaticography up to the medieval artes. Glotta 2019, 95, 101-134.

Ernout A. Morphologie historique du latin. Paris, Librairie C. Klincksieck, 1953.

Hertz M. (ed.) Prisciani Institutionum grammaticarum libri XVIII. Leipzig, Teubner, 1855-1859.

Holtz L. Donat et la tradition de l'enseignement grammatical. Etude sur l'Ars de Donat et sa diffusion (Ive-IXe siècle) et édition critique. Paris, CNRS, 1981.

Keil H. (ed.) Grammatici Latini. Leipzig, Teubner, 1855-1880.

Panhuis D. Latin Grammar. Ann Arbor, University of Michigan Press, 2006.

de Vaan M. Etymological Dictionary of Latin and the Other Italic Languages. Leiden, Brill, 2008.

Zetzel J.E. G. Critics, compilers, and commentators. An introduction to Roman philology, 200 BCE-800 CE. Oxford, OUP, 2018.

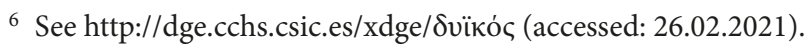

